\title{
Profile of circulating levels of IL-1Ra, CXCL10/IP-10, CCL4/MIP-1ß and CCL2/MCP-1 in dengue fever and parvovirosis
}

\author{
Luzia Maria de-Oliveira-Pinto ${ }^{1 /}{ }^{+}$, Mariana Gandini ${ }^{1}$, Laís Picinini Freitas ${ }^{1}$, \\ Marilda Mendonça Siqueira ${ }^{2}$, Cíntia Ferreira Marinho', Sérgio Setúbal ${ }^{3}$, \\ Claire Fernandes Kubelka', Oswaldo Gonçalves $\mathrm{Cruz}^{4}$, Solange Artimos de Oliveira ${ }^{3}$
}

${ }^{4}$ Programa de Computação Científica 'Laboratório de Imunologia Viral ${ }^{2}$ Laboratório de Vírus Respiratórios e de Sarampo, Instituto Oswaldo Cruz-Fiocruz, Av. Brasil 4365, 21045-900 Rio de Janeiro, RJ, Brasil ${ }^{3}$ Disciplina de Doenças Infecciosas e Parasitárias, Hospital Universitário Antônio Pedro, Universidade Federal Fluminense, Niterói, RJ, Brasil

Dengue virus (DENV) and parvovirus B19 (B19V) infections are acute exanthematic febrile illnesses that are not easily differentiated on clinical grounds and affect the paediatric population. Patients with these acute exanthematic diseases were studied. Fever was more frequent in DENV than in B19V-infected patients. Arthritis/arthralgias with DENV infection were shown to be significantly more frequent in adults than in children. The circulating levels of interleukin (IL)-1 receptor antagonist (Ra), CXCL10/inducible protein-10 (IP-10), CCL4/macrophage inflammatory protein-1 beta and CCL2/monocyte chemotactic protein-1 (MCP-1) were determined by multiplex immunoassay in serum samples obtained from B19V (37) and DENV-infected (36) patients and from healthy individuals (7). Forward stepwise logistic regression analysis revealed that circulating CXCL10/IP-10 tends to be associated with DENV infection and that IL-1Ra was significantly associated with DENV infection. Similar analysis showed that circulating CCL2/MCP-1 tends to be associated with B19V infection. In dengue fever, increased circulating IL-1Ra may exert antipyretic actions in an effort to counteract the already increased concentrations of IL-1 $\beta$, while CXCL10/IP-10 was confirmed as a strong pro-inflammatory marker. Recruitment of monocytes/macrophages and upregulation of the humoral immune response by CCL2/MCP-1 by B19V may be involved in the persistence of the infection. Children with B19V or DENV infections had levels of these cytokines similar to those of adult patients.

Key words: dengue - parvovirus B19 - chemokines - IL-1Ra

Among the many viruses that cause acute febrile rash illnesses, the most common are measles, rubella, herpes, varicella viruses, cytomegalovirus, Epstein-Barr virus, enteroviruses, human parvovirus B19 (B19V) and dengue virus (DENV) (Oliveira et al. 2008). The latter two were studied here because these induce acute disease and because no vaccines are available for either. Indeed, the high incidence in paediatric populations is a feature common to all these viruses even when effective vaccines are available (Ahmed et al. 2010). Although these paediatric viruses are commonly regarded as mild childhood diseases, complications may occur and frequently require hospitalisation (Elena et al. 2011, May et al. 2011). Further, additional investigations have linked infection with these viruses with a risk of developing autoimmune disorders (Krone et al. 2008) or cancers. In fact, acute $\mathrm{B} 19 \mathrm{~V}$-infection has been frequently observed in paediatric patients with haematological and/or oncological diseases. In patients with non-malignant diseases, anaemia or autoimmune disorders were diagnosed in association with B19V-infection (Jitschin et al. 2010). A retrospective hospital-based study was conducted in which the presence of spontaneous bleeding, hepatomegaly, signs

Financial support: FAPERJ, CNPq, FIOCRUZ

+ Corresponding author: 1pinto@ioc.fiocruz.br

Received 8 April 2011

Accepted 10 October 2011 of capillary leakage such as ascites and pleural effusion, leukopenia $<4.000 \mathrm{~mm}^{3}$ and age less than five years were found out to be significant risk factors of dengue shock syndrome (DSS) in paediatric patients with dengue haemorrhagic fever (DHF) (Gupta et al. 2011).

DENV, of which four serotypes have been identified (DENV 1-4), is a single-stranded, positive-sense RNA virus belonging to the genus Flavivirus of the Flaviviridae family. DENV usually causes an acute self-limited illness known as classic dengue fever (DF) that lasts five-seven days (Halstead 2007). Symptoms include high fever, headache, retro-orbital headache, myalgia, arthralgia, abdominal pain, nausea and vomiting. Less than $3 \%$ of patients developed severe forms (DHF/DSS) after a normal acute phase, characterised by an abrupt increase in capillary permeability and resulting plasma leakage that can lead to circulatory shock and death. Dengue is the most frequent human vector-borne viral disease. Two-fifths of the world populations are at risk and an estimated 50-100 million cases of DF occur each year worldwide (Gubler 2002a, b). Brazil reported approximately 1.5 million cases in 2009-2010 (MS/SVS $2010 \mathrm{a}, \mathrm{b})$ and 155,613 cases during the two first months of 2011 (MS/SVS 2011).

Despite the major health and economic impacts of this disease, there is currently no vaccine or specific treatment (Duyen et al. 2011). Severe disease may occasionally be seen during primary DENV infection, particularly in infants (Kliks et al. 1988, Chau et al. 2010); however, complications are usually described in association with sequential or secondary infections (Sangkaw- 
ibha et al. 1984, Halstead 2007). Antibody-dependent enhancement is thought to underlie this phenomenon (Halstead et al. 1970, Halstead \& O'Rourke 1977, Dejnirattisai et al. 2010). Moreover, the rapid activation of cross-reactive DENV-specific memory $\mathrm{T}$ cells generated during primary DENV infection appears to trigger strong production of proinflammatory cytokines, such as interferon (IFN)- $\gamma$, tumour necrosis factor (TNF)- $\alpha$ and interleukin (IL)-6, which can directly damage vascular endothelial cells, further resulting in plasma leakage (Mangada et al. 2002, Webster et al. 2009). DENVspecific $\mathrm{T}$ cells may have a dual role, both helping to clear the virus and causing bystander tissue damage. Numerous studies have explored the cytokine response to DENV. Proinflammatory cytokines, such as TNF- $\alpha$, IFN- $\gamma$, IL-6, IL-18 and macrophage migration inhibitory factor (MIF), are also known to be involved during the acute phase of the illness (Pinto et al. 1999, Braga et al. 2001, Bozza et al. 2008, Levy et al. 2010) and many chemokines involved in leukocyte recruitment to sites of infection, such as CXCL8/IL-8, CXCL10/inducible protein-10 (IP-10) and CCL2/monocyte chemotactic protein-1 (MCP-1), are produced during inflammation (Raghupathy et al. 1998, Hsieh et al. 2006, Lee et al. 2006). One study showed elevated IFN- $\alpha$ plasma levels shortly after symptom onset in DF children (Kurane et al. 1993). The severity of DENV infection seems to be due more to disproportionate inflammatory cytokine production than direct viral effects (Chaturvedi et al. 2007, Rothman 2009). Recently, a study was conducted in African DF patients infected during the first Gabonese DENV-2 outbreak in 2007. The concentrations of 50 cytokines, chemokines and growth factors were measured in plasma by Luminex technology (Bio-Rad). These data showed that relative to the controls, the patients had significantly elevated levels of growth factors (G-CSF, GM-CSF and VEGF-A), pro-inflammatory and antiviral cytokines (IL-6, Il-17 and IFN- $\alpha 2$ ), antiinflammatory cytokines [IL-1 receptor antagonist $(\mathrm{Ra})$, IL-2r $\alpha$ and IL-13], chemokines (IL-16, CCL2/MCP-1, CXCL10/IP-10, SDF-1 $\alpha$, MIF and CCL5/RANTES) and cytokines associated with adaptive responses (IL-7, IL$12 \mathrm{p} 40$ and IFN- $\gamma$ ) (Becquart et al. 2010).

B19V, a member of the family Parvoviridae and the genus Erythrovirus, is a non-enveloped, small singlestranded DNA virus. B19V is the aetiological agent of erythema infectiosum, a childhood rash disease and involved in a wide spectrum of other diseases (Young \& Brown 2004). Due to the destruction of erythroid precursor cells in bone marrow, the main targets for B19V replication affected patients develop anaemia, resulting in haematopoietic disorders (e.g., transient red cell aplasia, thrombocytopenia and pancytopenia in children and adults or hydrops fetalis in pregnant women) (Chorba et al. 1986, Yaegashi et al. 1998). Chronic immune activation and cytokine dysregulation occur in patients during and following symptomatic acute B19V-infection. It was shown that circulating IL- 6 , IFN- $\gamma$ and TNF- $\alpha$ are detectable in patients with symptomatic B19V-infection and that raised levels of IFN- $\gamma$ and TNF- $\alpha$ correlate with prolonged and chronic fatigue (Kerr et al. 2001). Cytokine dysregulation has been linked with B19V-associated haemophagocytosis and pancytopenia (Watanabe et al. 1994), arthritis (Wagner et al. 1995) and myocarditis (Nigro et al. 2000). Lymphocytes from convalescent adults produce high levels of IL- 2 and IFN- $\gamma$ in response to both B19V viral capsid VP1 and VP2 proteins (Corcoran et al. 2000). The levels of IL-6, TNF- $\alpha$ and GM-CSF at acute infection were lower in patients suffering from arthritis. There was also a trend towards lower levels of IFN- $\gamma$, CCL2/ MCP-1 and TGF- $\beta 1$ in acute B19V-associated arthritis and decreased level of serum TGF- $\beta 1$ in patients with rash. Moreover, a mixed Th1/Th2 cytokine profile was observed, as demonstrated by elevated levels of IFN- $\gamma /$ TNF- $\alpha$ and IL-4, respectively, in the sera of acute symptomatic B19V-infected patients (Kerr et al. 2004).

B19V and DENV have common features, as both are acute paediatric exanthematous diseases. Our first goal was to characterise a profile of chemokines and IL-1Ra in each of the viruses. We then investigated the association of the plasma levels of these soluble proteins in age subgroups ( $<15$ years or $\geq 15$ years) with clinical manifestations such as fever and arthritis/arthralgia.

\section{PATIENTS, MATERIALS AND METHODS}

Patient enrolment, assessment and serum collection - From 2001-2008, we prospectively included 37 patients with acute B19V infection and 36 patients with acute DENV infection. All patients were assisted at University Hospital Antônio Pedro (HUAP) at Fluminense Federal University, Niterói, state of Rio de Janeiro, Brazil. All patients presented acute exanthematic manifestations and were bled at the time or shortly after the onset of their symptoms, irrespective of their presumed clinical diagnosis. The disease history and physical examination of each patient were recorded. Patients with DF had DENV infection confirmed by anti-DENV enzyme-linked immunosorbent assay (ELISA)-IgM (Panbio, Inc, INDX ${ }^{\circledR}$ IVD $^{\mathrm{TM}}$ Microwell ELISA Dengue Fever IgM Test, Columbia, USA) and all other viral infections (e.g., measles, rubella or B19V) were excluded by serology. All patients had mild clinical manifestations; no haemorrhagic manifestations were observed and no hospitalisations were necessary. In B19V cases, the serum anti-B19V IgM test was positive (Biotrin Parvovirus Enzyme Immunoassay, Dublin, Ireland), while markers of other acute exanthematic infections (e.g., measles virus, rubella or DENVs) were negative. Seven healthy male controls (mean age of 31.6 years) were also enrolled in the study. The study was approved by HUAP Ethical Committee (CMM/HUAP 134/05). A written informed consent was signed by all patients or their guardians prior to blood collection.

Blood samples and chemokine/cytokine detection by multiplex microbead immunoassay - Blood samples were collected in pyrogen-free blood collection tubes and kept on ice. Serum was collected after centrifugation, divided in aliquots and stored at $-20^{\circ} \mathrm{C}$ until the assay. A multiplex biometric immunoassay containing fluorescent microspheres conjugated with monoclonal antibodies specific to the target proteins was used for cytokine measurement according to the manufacturer's 
instructions (Beadlyte ${ }^{\circledR}$ Human Multi-Cytokine Flex Kit; Upstate, Lake Placid, NY, USA). The cytokines measured were as follows: IFN-IP-10 (CXCL10/IP-10), MCP-1 (CCL2/MCP-1), macrophage inflammatory protein-1 beta (CCL4/MIP-1 $\beta$ ) and IL-1Ra. Briefly, $10 \mu \mathrm{L}$ plasma samples were diluted 1:10 and incubated with an antibody-coupled bead pool. The complexes were sequentially washed, incubated with a biotinylated detection antibody pool and streptavidin-phycoerythrin to detect the cytokine titres in sera. A range of $2.3-5.000 \mathrm{pg} /$ $\mathrm{mL}$ of the recombinant cytokines provided by the vendor (Upstate) was used to establish the standard curves, maximising the sensitivity and the dynamic range of the assay. Cytokine levels were determined using a multiplex array reader from Luminex ${ }^{\circledR} 200^{\mathrm{TM}}$ System (Luminex Corp). The analyte concentration was calculated from the respective standard curve by five-parameter logistic analysis using software provided by the manufacturer (xPONENT ${ }^{\circledR}$ v3.1 software).

Statistical analyses - The relationships between sex, days of onset symptoms and clinical manifestations were examined using Fisher's exact test. The nonparametric Kruskal-Wallis test was used to evaluate differences between cytokine ratios from acute B19V and DENV infected-patients. Generalised linear models (GLMs) were used to evaluate factors independently associated with quantitative variables. Analysis of factors independently associated with the two different viruses studied and other clinical manifestations was performed with GLMs with logistic or Gaussian regression. The results from the logistic regressions are given as odds ratio. The confidence interval was established at $95 \%$. Alternatively, for a GLM, Gaussian family t values were recorded. A probability value of $p<0.05$ was considered to be significant. The distributions of cytokine levels in the control and disease groups were normally distributed; comparisons of cytokine levels associated with clinical manifestations were carried out using the non-parametric Kruskal-Wallis test. Models were also built/constructed using logistic regression analysis to determine the clinical variables most strongly associated with the development of symptomatic infection. The statistical programs R ( $R$ : A language and environment for statistical computing) [R Foundation for Statistical Computing, Vienna, Austria, ISBN 3-900051-07-0 (Rproject.org)] and Prism 4 (Graph-Pad Software, San Diego, CA, USA) were used.

\section{RESULTS}

Clinical characterisation of acute exanthematic diseases caused by DENV or B19V in Brazilian patients - Detailed demographic, clinical and laboratory data from acutely DENV and B19-infected patients are summarised in Table I. DENV-infected patients were more likely to develop fever, independent of age, as compared to acutely B19V-infected patients. The development of arthritis or arthralgias in DENV infections was shown to be significantly more frequent in adults ( $\geq 15$ years) than in children $(<15$ years).

Circulating cytokines in DENV and B19V patients - Acutely DENV and B19V-infected patients showed elevated serum levels of CXCL10/IP-10 and CCL4/MIP$1 \beta$ (Figure, Table II) as compared to healthy individuals that usually have low or undetectable levels of these cytokines. CCL2/MCP-1 was significantly increased only in B19V patients as compared to controls, while IL-1Ra levels were higher in DENV-infected patients as compared to controls and B19V-infected patients. There was also a tendency towards increased levels of CCL2/ MCP-1 in DENV-infected patients and IL-1Ra in B19Vinfected patients, although the differences are not significant as compared to controls. In general, children with

TABLE I

Demographic information about the study population with acute dengue virus (DENV) or parvovirus B19 (B19V) infection ${ }^{a}$

\begin{tabular}{|c|c|c|c|c|}
\hline & \multicolumn{2}{|c|}{ DENV infection } & \multicolumn{2}{|c|}{ B19V infection } \\
\hline & Children & Adults & Children & Adults \\
\hline Patients (n) & 18 & 18 & 17 & 20 \\
\hline Mean age (range in years) & $6.5(0-12)$ & $32.5(15-77)$ & $6.3(1-14)$ & $26.8(16-55)$ \\
\hline Female:male ratio & 1.3:1 & $2: 1$ & $0.5: 1$ & $9: 1^{b}$ \\
\hline Mean days of disease (range in days) & $5.4(2-10)$ & $6.4(1-15)$ & $8.9(1-25)$ & $6.5(1-14)$ \\
\hline Fever $[\mathrm{n}(\%)]$ & $13(72)$ & $16(89)$ & $8(47)$ & $6(30)$ \\
\hline $\operatorname{Rash}[\mathrm{n}(\%$ total $)]$ & 100 & 100 & 100 & 100 \\
\hline Arthritis or arthralgias $[\mathrm{n}(\%$ total $)]$ & 0 & $13(65)^{c}$ & $2(11)$ & $7(39)$ \\
\hline Warning signs $[\mathrm{n}(\%$ total $)]$ & $7(41)$ & $4(20)$ & $5(28)$ & $6(33)$ \\
\hline Serum anti-B19V VP2 IgM & 0 & 0 & 100 & 100 \\
\hline Serum anti-DENV IgM & 100 & 100 & 0 & 0 \\
\hline
\end{tabular}

$a$ : children $<15$ years, adults $\geq 15$ years; $b: \mathrm{p}<0.001 ; c: \mathrm{p}<0.0001$. Significant difference between children and adults by Fisher's exact test analysis between children and adults within the same virus disease. 
A

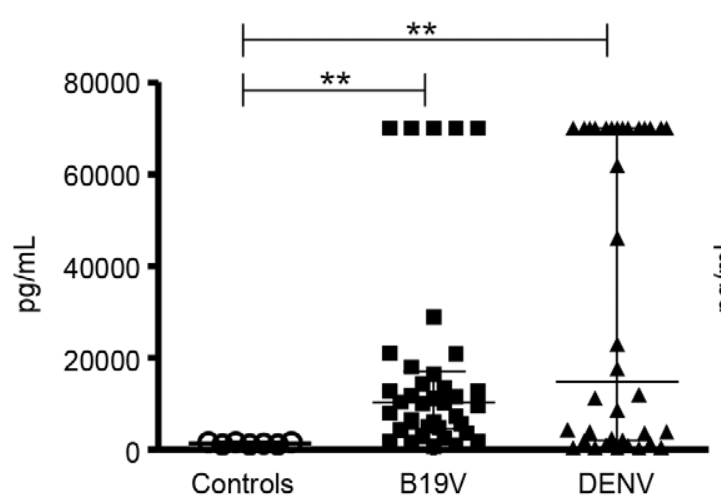

C

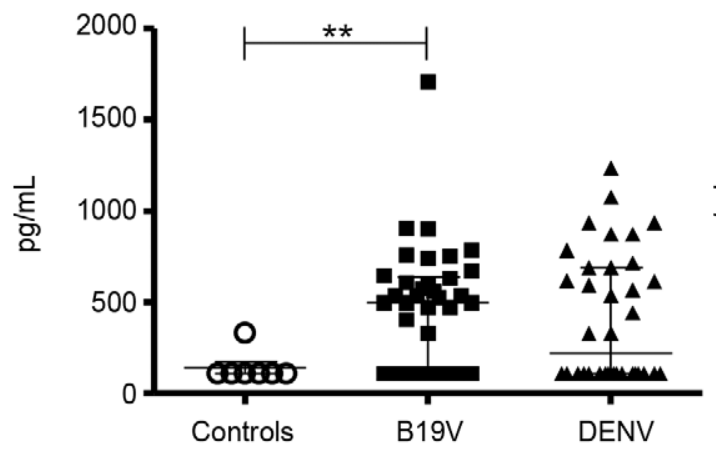

B

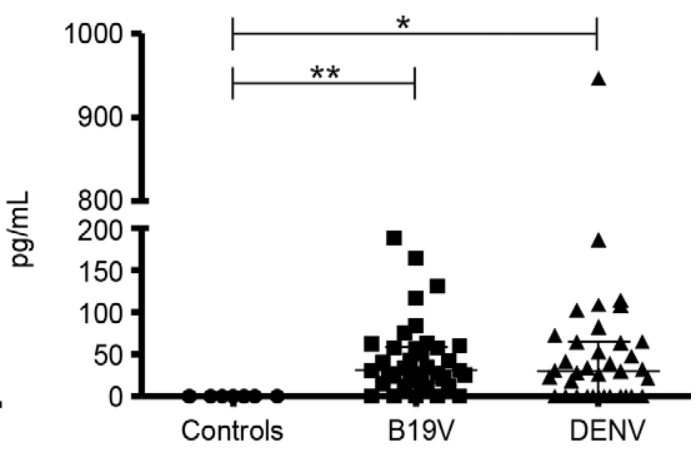

D

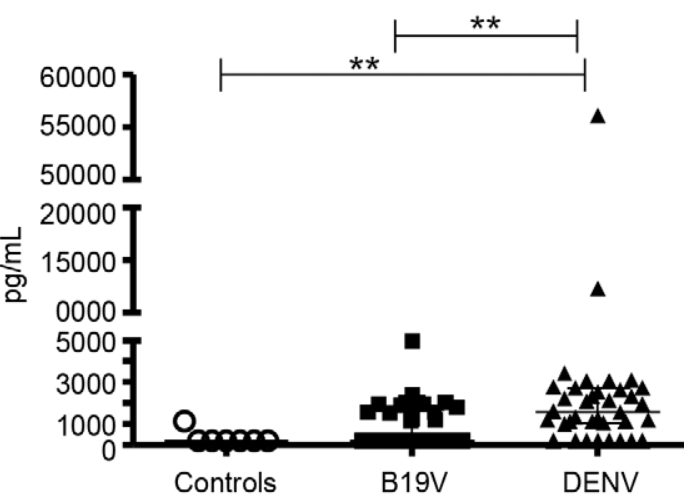

Chemokines and interleukin-1 receptor antagonist (IL-1Ra) levels in serum from patients with parvovirus B19 (B19V) or dengue scatter dot plots graph. The lines extend from the 25th to the 75th percentile and the line at the middle is the median. Non-parametric Kruskal-Wallis test was used to evaluate differences between circulating proteins concentrations from B19V, dengue virus (DENV) patients and controls. IP-10: inducible protein10; MCP-1: monocyte chemotactic protein-1; MIP-1 $\beta$ : macrophage inflammatory protein-1 beta; *: $\mathrm{p}<0.05 ; * *$ : $\mathrm{p}<0.01$ and $<0.001$.

B19V or DENV infections had levels of these cytokines similar to those of adult patients. However, compared to CXCL10/IP-10 plasma levels in DENV infection, the median values of this chemokine in adult patients [9.897 (1.986-70.000) pg/mL] were lower than those in children [53.972 (1.163-70.000) pg/mL], although this difference is not significant. The high cytokine levels in patients with acute B19V or DENV infection demonstrate the importance of this host response. It remains to be determined which cytokines, if any, are associated with clinical manifestations.

Distinctive associations between circulating cytokines and clinical manifestations in exanthematic diseases caused by DENV and B19V - Multivariate logistic regression models were constructed to determine the individual, clinical and circulating cytokines/chemokines variables most strongly associated with the development of symptomatic infection, while also correcting for the effect of possible confounding variables. Fever was positively associated with IL-1Ra levels but negatively associated with CCL4/MIP-1 $\beta$ production irrespective of the associated virus (Table III). No association was found between CXCL10/IP-10 and CCL2/MCP-1 levels and fever. Another logistic regression model confirmed that arthritis/arthralgias were associated with adult patients, as observed previously (de Oliveira et al. 2009). Significant associations of arthritis/arthralgias with cytokines/chemokines (Table IV) or with premonitory signs (data not shown) could not be found in either infection.

A forward stepwise logistic regression revealed a third model in which age, sex and disease duration were parameters independently associated with the infecting virus type. In this model, there was a weak direct association between CCL2/MCP-1 levels and B19V infection. Furthermore, we found a negative association between fever, the levels of CXCL10/IP-10 (weakly) and IL-1$\mathrm{Ra}$ with $\mathrm{B} 19 \mathrm{~V}$ infection, indicating that these variables could influence the manifestations of DENV infection more than those induced by B19V infection (Table V). 
TABLE II

Cytokines/chemokines levels from patients with acute dengue virus (DENV), parvovirus B19 (B19V) and healthy controls ${ }^{a}$

\begin{tabular}{|c|c|c|c|c|c|}
\hline & \multicolumn{2}{|c|}{$\begin{array}{l}\text { DENV infection } \\
(\mathrm{pg} / \mathrm{mL})\end{array}$} & \multicolumn{2}{|c|}{$\begin{array}{l}\text { B19V infection } \\
(\mathrm{pg} / \mathrm{mL})\end{array}$} & \multirow[t]{2}{*}{$\begin{array}{l}\text { Controls } \\
(\mathrm{pg} / \mathrm{mL})\end{array}$} \\
\hline & Children & Adults & Children & Adults & \\
\hline CXCL10/IP-10 & $\begin{array}{c}53.972 \\
(1.163-70.000)\end{array}$ & $\begin{array}{c}9.897 \\
(1.986-70.000)\end{array}$ & $\begin{array}{c}8.718 \\
(3.693-16.777)\end{array}$ & $\begin{array}{c}1.1067 \\
(5.455-18.595)\end{array}$ & $\begin{array}{c}1.142 \\
(1.035-1.455)\end{array}$ \\
\hline CCL4/MIP-1 $\beta$ & $\begin{array}{c}24.63 \\
(0.01-55.70)\end{array}$ & $\begin{array}{c}37.67 \\
(13.72-104.0)\end{array}$ & $\begin{array}{c}26.85 \\
(13.08-54.90)\end{array}$ & $\begin{array}{c}34.80 \\
(20.82-69.30)\end{array}$ & $\begin{array}{c}0.01 \\
(0.01-0.01)\end{array}$ \\
\hline CCL2/MCP-1 & $\begin{array}{c}276.4 \\
(109.7-632.1)\end{array}$ & $\begin{array}{c}220.4 \\
(109.7-755.4)\end{array}$ & $\begin{array}{c}496.3 \\
(109.7-660.9)\end{array}$ & $\begin{array}{c}499.3 \\
(220.4-626.5)\end{array}$ & $\begin{array}{c}109.7 \\
(109.7-109.7)\end{array}$ \\
\hline IL-1Ra & $\begin{array}{c}1361 \\
(219.5-2.572)\end{array}$ & $\begin{array}{c}1885 \\
(1191-2.849)\end{array}$ & $\begin{array}{c}219.5 \\
(219.5-1.755)\end{array}$ & $\begin{array}{c}219.5 \\
(219.5-1.736)\end{array}$ & $\begin{array}{c}219.5 \\
(219.5-219.5)\end{array}$ \\
\hline
\end{tabular}

$a$ : children $<15$ years, adults $\geq 15$ years; IL-1Ra: interleukin-1 receptor antagonist; IP-10: inducible protein-10; MCP-1: monocyte chemotactic protein-1; MIP-1 $\beta$ : macrophage inflammatory protein-1 beta.

TABLE III

Forward stepwise logistic regression analysis to determine the immunological variables most strongly associated with fever in acute dengue virus and parvovirus B19 infection ${ }^{a}$

\begin{tabular}{|c|c|c|c|c|}
\hline $\begin{array}{l}\text { Fever }(n) \\
(\text { yes }=44 ; \text { no }=29)\end{array}$ & $\begin{array}{l}\text { Regression } \\
\text { coefficient }\end{array}$ & SE & $\begin{array}{c}\text { OR } \\
(95 \% \mathrm{CI})\end{array}$ & $\mathrm{p}$ \\
\hline Intercept & 0.095 & 0.475 & & 0.842 \\
\hline CXCL10/IP-10 & $2.0 \mathrm{e}-05$ & $1.1 \mathrm{e}-05$ & $1.000(1.000-1.000)$ & 0.073 \\
\hline CCL4/MIP-1 $\beta$ & -0.017 & 0.008 & $0.983(0.967-0.999)$ & $0.04^{b}$ \\
\hline CCL2/MCP-1 & $-7.5 e-05$ & $9.1 \mathrm{e}-04$ & $1.000(0.998-1.002)$ & 0.935 \\
\hline IL-1Ra & $3.0 \mathrm{e}-04$ & $1.4 \mathrm{e}-04$ & $1.000(1.000-1.001)$ & $0.036^{b}$ \\
\hline Age $(<15$ years $)$ & 0.326 & 0.535 & $1.386(0.486-3.950)$ & 0.542 \\
\hline
\end{tabular}

$a$ : models were chosen according to their best Akaike information criterion; $b$ : $<0.05$; CI: confidence interval; IL-1Ra: interleukin-1 receptor antagonist; IP-10: inducible protein-10; MCP-1: monocyte chemotactic protein-1; MIP-1 $\beta$ : macrophage inflammatory protein-1 beta; OR: odds ratio; SE: standard error.

TABLE IV

Forward stepwise logistic regression analysis to determine the clinical and laboratorial/immunological variables associated with arthritis or arthralgias in acute parvovirus B19 and dengue virus infection ${ }^{a}$

\begin{tabular}{|c|c|c|c|c|}
\hline $\begin{array}{l}\text { Arthritis/arthralgia }(\mathrm{n}) \\
(\text { yes }=22 ; \text { no }=51)\end{array}$ & $\begin{array}{l}\text { Regression } \\
\text { coefficient }\end{array}$ & $\mathrm{SE}$ & $\begin{array}{c}\text { OR } \\
(95 \% \mathrm{CI})\end{array}$ & $\mathrm{p}$ \\
\hline Intercept & 0.175 & 0.523 & & 0.738 \\
\hline CXCL10/IP-10 & $-4.8 \mathrm{e}-06$ & $1.2 \mathrm{e}-05$ & $1.000(0.999-1.000)$ & 0.679 \\
\hline CCL4/MIP-1 $\beta$ & -0.005 & 0.0107 & $0.995(0.975-1.016)$ & 0.655 \\
\hline CCL2/MCP-1 & $3.9 \mathrm{e}-04$ & 0.001 & $1.000(0.998-1.002)$ & 0.714 \\
\hline IL-1Ra & $5.1 \mathrm{e}-05$ & $2.1 \mathrm{e}-04$ & $1.000(0.999-1.000)$ & 0.807 \\
\hline Age $(<15$ years $)$ & -2.884 & 0.824 & $0.056(0.011-0.281)$ & $0.001^{b}$ \\
\hline
\end{tabular}

$a$ : models were chosen according to their best Akaike information criterion; $b$ : $<0.001$; CI: confidence interval; IL-1Ra: interleukin-1 receptor antagonist; IP-10: inducible protein-10; MCP-1: monocyte chemotactic protein-1; MIP-1 $\beta$ : macrophage inflammatory protein-1 beta; OR: odds ratio; SE: standard error. 
TABLE V

Forward stepwise logistic regression analysis to determine the clinical and immunological variables associated with parvovirus B19 (B19V) or dengue virus infection ${ }^{a}$

\begin{tabular}{|c|c|c|c|c|}
\hline $\begin{array}{l}\text { B19V infection } \\
(\text { yes }=37 ; \text { no }=36)\end{array}$ & $\begin{array}{l}\text { Regression } \\
\text { coefficient }\end{array}$ & SE & OR $(95 \% \mathrm{CI})$ & $\mathrm{p}$ \\
\hline Intercept & 8.783 & 2.932 & & $0.003^{b}$ \\
\hline$<15$ years & -0.917 & 0.831 & $0.400(0.078-2.038)$ & 0.270 \\
\hline Male sex & 1.739 & 0.891 & $5.693(0.994-0.326)$ & 0.051 \\
\hline Days of onset symptoms & 0.170 & 0.099 & $1.185(0.975-1.440)$ & 0.088 \\
\hline Fever & -3.090 & 0.926 & $0.046(0.007-0.279)$ & $0.001^{b}$ \\
\hline CXCL10/IP-10 & $-5.1 \mathrm{e}-05$ & $1.8 \mathrm{e}-05$ & $0.999(0.999-1.000)$ & $0.004^{b}$ \\
\hline CCL4/MIP-1 $\beta$ & 0.006 & 0.005 & $1.006(0.996-1.016)$ & 0.217 \\
\hline CCL2/MCP-1 & 0.005 & 0.002 & 1.005 (1.002-1.009) & $0.005^{b}$ \\
\hline Log IL-1Ra & -1.375 & 0.463 & $0.253(0.102-0.626)$ & $0.003^{b}$ \\
\hline
\end{tabular}

$a$ : models were chosen according to their best Akaike information criterion; $b$ : $<0.01$; CI: confidence interval; IL-1Ra: interleukin-1 receptor antagonist; IP-10: inducible protein-10; MCP-1: monocyte chemotactic protein-1; MIP-1 $\beta$ : macrophage inflammatory protein-1 beta; OR: odds ratio; SE: standard error.

\section{DISCUSSION}

Several cytokines and chemokines have been reported to be induced as a response to DENV in vitro and in vivo, but few detailed studies on B19V infection have been performed. The experimental approach used here was the analysis of the circulating proteins IL-1Ra, CXCL10/IP-10, CCL4/MIP-1 $\beta$ and CCL2/MCP-1 in clinical samples from DENV or B19V-infected patients exhibiting characteristic exanthemas during the acute phase of the disease. Moreover, considering the importance of both viruses in the paediatric cohort, we evaluated this panel of circulating proteins in children and adult patients. The results presented here show higher serum levels of CXCL10/IP-10 and IL-1Ra in DENV-infected patients compared with $\mathrm{B} 19 \mathrm{~V}$-infected patients, while higher serum levels of CCL2/MCP-1 were detected in acute B19V infections. There were no differences in the levels of proteins between age groups.

Pro-inflammatory cytokines with short half-lives are rapidly cleared from circulation. In contrast, soluble inhibitors have much longer circulating half-lives and thus may reflect more accurately the production of the inflammatory cytokines, giving us useful information about how to monitor these diseases. In this study, other inflammatory cytokines were tested in the same multiplex biometric immunoassay; however, we obtained only detectable levels of a few chemokines and IL-1Ra. Among the cytokines found, TNF- $\alpha$ and IL-1 $1 \beta$ serve as important mediators in the evolution of inflammatory diseases by stimulating other pro-inflammatory mediators, such as IL-6 and IL-8. Several endogenous mechanisms limit the systemic activity of recently produced TNF and IL-1 (Dinarello 1995). IL-1 regulation is mediated by the balance between its specific IL-1Ra and soluble IL-1 receptors (Arend 1993, 2002, Firestein et al. 1994). An earlier report on another cohort of Brazilian DF patients showed that only $16 \%$ had altered IL-1Ra levels (Pinto et al. 1999). Here, significantly elevated levels of the antiinflammatory cytokine IL-1Ra were detected in DENV patients. This was not true for B19V patients and controls. Another interesting observation is that fever with either one of these exanthematic diseases is positively associated with IL-1Ra levels. It is well known that IL$1 \beta$, a major mediator of lipopolysaccharide-induced fever, elicits febrile responses via cyclooxygenase-2-dependent production of prostaglandin $\mathrm{E}_{2}$ in the brain (Kluger 1991, Li et al. 2001). The IL-1-induced fever can be attenuated by the central administration of neutralising anti-IL-1 $\beta$ (Klir et al. 1994, Gourine et al. 1998) or naturally occurring IL-1Ra (Luheshi et al. 1996, Miller et al. 1997). This observation raises the possibility that circulating IL-1Ra may exert its antipyretic action and may be produced as a feedback mechanism in an effort to counteract the early increase of IL-1 $\beta$ levels in DF.

CCL2/MCP-1 is a potent chemotactic factor for monocytes/macrophages (Gu et al. 1997), both major sources of CCL2 (Yoshimura et al. 1989). In addition, CCL2 regulates the migration and tissue infiltration of memory $\mathrm{T}$ lymphocytes and natural killer (NK) cells. CCL2 is produced by many cell types, including endothelial, fibroblast, epithelial, smooth muscle, mesangial, astrocyte and microglial cells (Cushing et al. 1990, Standiford et al. 1991, Brown et al. 1992, Barna et al. 1994). These cells are important for the anti-viral immune responses in the peripheral circulation and tissues. Accordingly, the study of Kerr et al. (2004) on B19V infection found a significant number of acutely infected patients with high CCL2/MCP-1 levels. The authors also demonstrated a trend towards lower CCL2/MCP-1 levels in acute B19V-associated arthritis and a negative association with rheumatoid factor production. Our data confirmed a direct association between CCL2/ MCP-1 levels and B19V infection. However, no significant association was observed between CCL2/MCP-1 
and DENV infection. The forward stepwise logistic regression analysis showed a significant association of arthritis/arthralgias with patient age $\geq 15$ years independent of the virus. It is possible that studies with a higher number of patients would be more accurate with respect to this association, but also may indicate that both diseases behave similarly in this aspect.

The induction of several chemokines in DENV infection has been reported. Elevated levels of CXCL8/ IL-8 (Raghupathy et al. 1998, Juffrie et al. 2000), CCL2/ MCP-1 (Lee et al. 2006) and CXCL10/IP-10 (Fink et al. 2007) have been observed in dengue patients, mainly in more severe cases. Increased CCL4/MIP-1 $\beta$ levels were detected in patients with mild dengue when compared with the more severe forms of the disease. In addition, CCL2/MCP-1 levels were associated with marked thrombocytopenia and hypotension (Bozza et al. 2008). Recently, Becerra et al. (2009) showed higher circulating CCL8/MCP-2 and CXCL10/IP-10 levels during the febrile course of DF. Another interesting study from Chau et al. (2008) evaluated circulating levels of chemokines during acute DF. Plasma CXCL10/IP-10 levels were significantly higher in infants with dengue and significantly correlated with DENV viral loads in the same sample. Moreover, their data showed that CXCL10/IP-10 is associated with viremia during acute primary dengue infections in infants. Dejnirattisai et al. (2008) found that CXCL10 levels were higher in DHF than in DF patients before defervescence, but showed no significant difference at the defervescence day. Our data confirm a direct association between CXCL10/IP-10 levels and DENV infection that was not observed during $\mathrm{B} 19 \mathrm{~V}$ infection.

CXCL10, also known as IFN- $\gamma$-IP-10, is a chemoattractant for activated $\mathrm{T}$ and $\mathrm{NK}$ cells bearing CXCR3, the chemokine receptor for CXCL9, CXCL10 and CXCL11 (Loetscher et al. 1996). Hsieh et al. (2006) showed that both CXCR3 and CXCL10 deficient (CXCR3-/- and CXCL10-/-) mice presented higher mortality than wildtype (WT) mice following DENV infection. Moreover, CXCR3-/- mice developed increased mortality accompanied by increased viral titres and reduced $\mathrm{T}$ cell infiltration in infected brain tissue as compared to WT mice, suggesting that CXCR 3 plays a critical role in host defence by mobilising $\mathrm{T}$ cells into DENV-infected brain tissue for viral clearance. Recently, Ip and Liao (2010) investigated CXCL10 antiviral activity in DENV infection. Unexpectedly, the recruitment of effector cells into sites of infection was not impaired in CXCL10-/mice. Furthermore, primary neuronal cells infected with DENV produced CXCL10, but not CXCL9 and CXCL10 inhibited viral infection in neuronal cells by competing with DENV for binding to heparan sulphate, a co-receptor for DENV entry. Their data support an unappreciated role for CXCL10 in innate host defence against DENV infection, reducing mortality during DENV infection. According to our results, CXCL10/IP-10 was confirmed as a strong pro-inflammatory marker in acute DENV disease, explaining perhaps the quicker virus clearance and recovery in these patients. In the future, it would be interesting to conduct ex vivo studies evaluating peripheral mononu- clear cells obtained from DENV patients for chemokine receptor induction on immune cells and their impact on the regulatory immune response during infection.

The present data confirm and extend previous observations that unregulated production of chemokines/ cytokines are found in the circulation of patients with acute symptomatic infections with B19V or DENV as compared with non-infected individuals. In short, our data are a distinctive and comparative profile of some circulating proteins between DF and parvovirosis. We conclude that circulating IL-1Ra and CXCL10/IP-10 seem to prevail during DF, while CCL2/MCP-1 is most prevalent in $\mathrm{B} 19 \mathrm{~V}$.

\section{ACKNOWLEDGEMENTS}

To Dr Andrea Alice da Silva and Adriano, for technical support.

\section{REFERENCES}

Ahmed PA, Babaniyi IB, Otuneye AT 2010. Review of childhood measles admissions at the National Hospital, Abuja. Niger J Clin Pract 13: 413-416.

Arend WP 1993. Interleukin-1 receptor antagonist. Adv Immunol 54: 167-227.

Arend WP 2002. The balance between IL-1 and IL-1Ra in disease. Cytokine Growth Factor Rev 13: 323-340.

Barna BP, Pettay J, Barnett GH, Zhou P, Iwasaki K, Estes ML 1994. Regulation of monocyte chemoattractant protein-1 expression in adult human non-neoplastic astrocytes is sensitive to tumor necrosis factor (TNF) or antibody to the $55-\mathrm{kDa}$ TNF receptor. J Neuroimmunol 50: 101-107.

Becerra A, Warke RV, Martin K, Xhaja K, de Bosch N, Rothman AL, Bosch I 2009. Gene expression profiling of dengue infected human primary cells identifies secreted mediators in vivo. $J$ Med Virol 81: 1403-1411.

Becquart P, Wauquier N, Nkoghe D, Ndjoyi-Mbiguino A, Padilla C, Souris M, Leroy EM 2010. Acute dengue virus 2 infection in Gabonese patients is associated with an early innate immune response, including strong interferon alpha production. $B M C$ Infect Dis 10: 356 .

Bozza FA, Cruz OG, Zagne SM, Azeredo EL, Nogueira RM, Assis EF, Bozza PT, Kubelka CF 2008. Multiplex cytokine profile from dengue patients: MIP-1beta and IFN-gamma as predictive factors for severity. BMC Infect Dis 8: 86 .

Braga EL, Moura P, Pinto LM, Ignacio SR, Oliveira MJ, Cordeiro MT, Kubelka CF 2001. Detection of circulant tumor necrosis factoralpha, soluble tumor necrosis factor p75 and interferon-gamma in Brazilian patients with dengue fever and dengue hemorrhagic fever. Mem Inst Oswaldo Cruz 96: 229-232.

Brown Z, Strieter RM, Neild GH, Thompson RC, Kunkel SL, Westwick J 1992. IL-1 receptor antagonist inhibits monocyte chemotactic peptide 1 generation by human mesangial cells. Kidney Int 42: 95-101.

Chaturvedi UC, Shrivastava R, Tripathi RK, Nagar R 2007. Dengue virus-specific suppressor T cells: current perspectives. FEMS Immunol Med Microbiol 50: 285-299.

Chau TN, Anders KL, Lien le B, Hung NT, Hieu LT, Tuan NM, Thuy TT, Phuong le T, Tham NT, Lanh MN, Farrar JJ, Whitehead SS, Simmons CP 2010. Clinical and virological features of dengue in Vietnamese infants. PLoS Negl Trop Dis 4: e657.

Chau TN, Quyen NT, Thuy TT, Tuan NM, Hoang DM, Dung NT, 
Lien le B, Quy NT, Hieu NT, Hieu LT, Hien TT, Hung NT, Farrar J, Simmons CP 2008. Dengue in Vietnamese infants - results of infection-enhancement assays correlate with age-related disease epidemiology and cellular immune responses correlate with disease severity. J Infect Dis 198: 516-524.

Chorba T, Coccia P, Holman RC, Tattersall P, Anderson LJ, Sudman J, Young NS, Kurczynski E, Saarinen UM, Moir R 1986. The role of parvovirus B19 in aplastic crisis and erythema infectiosum (fifth disease). J Infect Dis 154: 383-393.

Corcoran A, Doyle S, Waldron D, Nicholson A, Mahon BP 2000. Impaired gamma interferon responses against parvovirus B19 by recently infected children. $J$ Virol 74: 9903-9910.

Cushing SD, Berliner JA, Valente AJ, Territo MC, Navab M, Parhami F, Gerrity R, Schwartz CJ, Fogelman AM 1990. Minimally modified low density lipoprotein induces monocyte chemotactic protein 1 in human endothelial cells and smooth muscle cells. Proc Natl Acad Sci USA 87: 5134-5138.

de Oliveira SA, Bastos Camacho LA, Fernandes Bruno L, de Gusmao RC, de Medeiros Pereira AC, Coca Velarde LG, Mendonca Siqueira M 2009. Acute arthropathy in patients with rash diseases: a comparative study. Clin Rheumatol 28: 1067-1071.

Dejnirattisai W, Duangchinda T, Lin CL, Vasanawathana S, Jones M, Jacobs M, Malasit P, Xu XN, Screaton G, Mongkolsapaya J 2008. A complex interplay among virus, dendritic cells, T cells and cytokines in dengue virus infections. J Immunol 181: 5865-5874.

Dejnirattisai W, Jumnainsong A, Onsirisakul N, Fitton P, Vasanawathana S, Limpitikul W, Puttikhunt C, Edwards C, Duangchinda T, Supasa S, Chawansuntati K, Malasit P, Mongkolsapaya J, Screaton G 2010. Cross-reacting antibodies enhance dengue virus infection in humans. Science 328: 745-748.

Dinarello CA 1995. Controlling the production of interleukin-1 and tumor necrosis factor in disease. Nutrition 11: 695-697.

Duyen HT, Ngoc TV, Ha DT, Hang VT, Kieu NT, Young PR, Farrar JJ, Simmons CP, Wolbers M, Wills BA 2011. Kinetics of plasma viremia and soluble nonstructural protein 1 concentrations in dengue: differential effects according to serotype and immune status. J Infect Dis 203: 1292-1300.

Elena B, Anna Q, Andrzej K, Elisabetta P, Laura L, Alberto T 2011. Haematological complications in otherwise healthy children hospitalized for varicella. Vaccine 29: 1534-1537.

Fink J, Gu F, Ling L, Tolfvenstam T, Olfat F, Chin KC, Aw P, George J, Kuznetsov VA, Schreiber M, Vasudevan SG, Hibberd ML 2007. Host gene expression profiling of dengue virus infection in cell lines and patients. PLoS Negl Trop Dis 1: e86.

Firestein GS, Boyle DL, Yu C, Paine MM, Whisenand TD, Zvaifler NJ, Arend WP 1994. Synovial interleukin-1 receptor antagonist and interleukin-1 balance in rheumatoid arthritis. Arthritis Rheum 37: 644-652.

Gourine AV, Leon LR, Rudolph K, Korsak AS, Kluger MJ 1998. Anterior hypothalamic interleukin-1 receptors are involved in mediation of fever during bacterial sepsis in rats. Ann NY Acad Sci 856: 266-269.

Gu L, Rutledge B, Fiorillo J, Ernst C, Grewal I, Flavell R, Gladue R, Rollins B 1997. In vivo properties of monocyte chemoattractant protein-1. J Leukoc Biol 62: 577-580.

Gubler DJ 2002a. Epidemic dengue/dengue hemorrhagic fever as a public health, social and economic problem in the 21st century. Trends Microbiol 10: 100-103.

Gubler DJ 2002b. The global emergence/resurgence of arboviral diseases as public health problems. Arch Med Res 33: 330-342.
Gupta V, Yadav TP, Pandey RM, Singh A, Gupta M, Kanaujiya P, Sharma A, Dewan V 2011. Risk factors of dengue shock syndrome in children. $J$ Trop Pediatr 57: 451-456.

Halstead SB 2007. Dengue. Lancet 370: 1644-1652.

Halstead SB, Nimmannitya S, Cohen SN 1970. Observations related to pathogenesis of dengue hemorrhagic fever. IV. Relation of disease severity to antibody response and virus recovered. Yale $J$ Biol Med 42: 311-328.

Halstead SB, O'Rourke EJ 1977. Antibody-enhanced dengue virus infection in primate leukocytes. Nature 265: 739-741.

Hsieh MF, Lai SL, Chen JP, Sung JM, Lin YL, Wu-Hsieh BA, Gerard C, Luster A, Liao F 2006. Both CXCR3 and CXCL10/IFN-inducible protein 10 are required for resistance to primary infection by dengue virus. J Immunol 177: 1855-1863.

Ip PP, Liao F 2010. Resistance to dengue virus infection in mice is potentiated by CXCL10 and is independent of CXCL10-mediated leukocyte recruitment. J Immunol 184: 5705-5714.

Jitschin R, Peters O, Plentz A, Turowski P, Segerer H, Modrow S 2010. Impact of parvovirus B19 infection on paediatric patients with haematological and/or oncological disorders. Clin Microbiol Infect 17: 1336-1342.

Juffrie M, van Der Meer GM, Hack CE, Haasnoot K, Veerman AJ, Thijs LG 2000. Inflammatory mediators in dengue virus infection in children: interleukin- 8 and its relationship to neutrophil degranulation. Infect Immun 68: 702-707.

Kerr JR, Barah F, Mattey DL, Laing I, Hopkins SJ, Hutchinson IV, Tyrrell DA 2001. Circulating tumour necrosis factor-alpha and interferon-gamma are detectable during acute and convalescent parvovirus B19 infection and are associated with prolonged and chronic fatigue. J Gen Virol 82: 3011-3019.

Kerr JR, Cunniffe VS, Kelleher P, Coats AJ, Mattey DL 2004. Circulating cytokines and chemokines in acute symptomatic parvovirus B19 infection: negative association between levels of pro-inflammatory cytokines and development of B19-associated arthritis. J Med Virol 74: 147-155.

Kliks SC, Nimmanitya S, Nisalak A, Burke DS 1988. Evidence that maternal dengue antibodies are important in the development of dengue hemorrhagic fever in infants. Am J Trop Med Hyg 38: 411-419.

Klir JJ, McClellan JL, Kluger MJ 1994. Interleukin-1 beta causes the increase in anterior hypothalamic interleukin-6 during LPS-induced fever in rats. Am J Physiol 266: R1845-1848.

Kluger MJ 1991. Fever: role of pyrogens and cryogens. Physiol Rev 71: 93-127.

Krone B, Pohl D, Rostasy K, Kahler E, Brunner E, Oeffner F, Grange JM, Gartner J, Hanefeld F 2008. Common infectious agents in multiple sclerosis: a case-control study in children. Mult Scler 14: 136-139.

Kurane I, Innis BL, Nimmannitya S, Nisalak A, Meager A, Ennis FA 1993. High levels of interferon alpha in the sera of children with dengue virus infection. Am J Trop Med Hyg 48: 222-229.

Lee YR, Liu MT, Lei HY, Liu CC, Wu JM, Tung YC, Lin YS, Yeh TM, Chen SH, Liu HS 2006. MCP-1, a highly expressed chemokine in dengue haemorrhagic fever/dengue shock syndrome patients may cause permeability change, possibly through reduced tight junctions of vascular endothelium cells. J Gen Virol 87: 3623-3630.

Levy A, Valero N, Espina LM, Anez G, Arias J, Mosquera J 2010. Increment of interleukin 6, tumour necrosis factor alpha, nitric oxide, C-reactive protein and apoptosis in dengue. Trans $R$ Soc Trop Med Hyg 104: 16-23. 
Li S, Ballou LR, Morham SG, Blatteis CM 2001. Cyclooxygenase-2 mediates the febrile response of mice to interleukin-1beta. Brain Res 910: 163-173.

Loetscher P, Seitz M, Clark-Lewis I, Baggiolini M, Moser B 1996. Activation of NK cells by $\mathrm{CC}$ chemokines. Chemotaxis, $\mathrm{Ca}^{2+}$ mobilization and enzyme release. J Immunol 156: 322-327.

Luheshi G, Miller AJ, Brouwer S, Dascombe MJ, Rothwell NJ, Hopkins SJ 1996. Interleukin-1 receptor antagonist inhibits endotoxin fever and systemic interleukin-6 induction in the rat. Am J Physiol 270: E91-95.

Mangada MM, Endy TP, Nisalak A, Chunsuttiwat S, Vaughn DW, Libraty DH, Green S, Ennis FA, Rothman AL 2002. Denguespecific $\mathrm{T}$ cell responses in peripheral blood mononuclear cells obtained prior to secondary dengue virus infections in Thai schoolchildren. J Infect Dis 185: 1697-1703.

May LJ, Patton DJ, Fruitman DS 2011. The evolving approach to paediatric myocarditis: a review of the current literature. Cardiol Young 21: 241-251.

Miller AJ, Hopkins SJ, Luheshi GN 1997. Sites of action of IL-1 in the development of fever and cytokine responses to tissue inflammation in the rat. Br J Pharmacol 120: 1274-1279.

MS - Ministério da Saúde/Secretaria de Vigilância em Saúde 2010a. Informe Epidemiológico da dengue - semanas 1 a 52 2009. Available from: portal.saude.gov.br/portal/arquivos/pdf/informe_epidemiologico_semana_1a52_09_revisado.pdf.

MS/SVS - Ministério da Saúde/Secretaria de Vigilância em Saúde 2010b. Clipping 13, 14 e 15 November 2010. Available from: portal. saude.gov.br/portal/arquivos/pdf/clipping_13_14_15_11_2010.pdf.

MS/SVS - Ministério da Saúde/Secretaria de Vigilância em Saúde 2011. SVS em rede. Available from: 189.28.128.179:8080/svs_informa/imagens-1/dengue-2011-tabela-1/view.

Nigro G, Bastianon V, Colloridi V, Ventriglia F, Gallo P, D’Amati G, Koch WC, Adler SP 2000. Human parvovirus B19 infection in infancy associated with acute and chronic lymphocytic myocarditis and high cytokine levels: report of 3 cases and review. Clin Infect Dis 31: 65-69.

Oliveira MJ, Cordeiro MT, Costa FM, Murakami G, Silva AM, Travassos RC, Magalhaes V 2008. Frequency of measles, rubella, dengue and erythema infectiosum among suspected cases of measles and rubella in the state of Pernambuco between 2001 and 2004. Rev Soc Bras Med Trop 41: 338-344.
Pinto LM, Oliveira SA, Braga ELA, Nogueira RMR, Kubelka CF 1999. Increased pro-inflammatory cytokines (TNF-alpha and IL-6) and anti-inflammatory compounds (sTNFRp55 and sTNFRp75) in Brazilian patients during exanthematic dengue fever. Mem Inst Oswaldo Cruz 94: 387-394.

Raghupathy R, Chaturvedi UC, Al-Sayer H, Elbishbishi EA, Agarwal R, Nagar R, Kapoor S, Misra A, Mathur A, Nusrat H, Azizieh F, Khan MA, Mustafa AS 1998. Elevated levels of IL-8 in dengue hemorrhagic fever. J Med Virol 56: 280-285.

Rothman AL 2009. T lymphocyte responses to heterologous secondary dengue virus infections. Ann NY Acad Sci 1171 (Suppl. 1): E36-E41.

Sangkawibha N, Rojanasuphot S, Ahandrik S, Viriyapongse S, Jatanasen S, Salitul V, Phanthumachinda B, Halstead SB 1984. Risk factors in dengue shock syndrome: a prospective epidemiologic study in Rayong, Thailand. I. The 1980 outbreak. Am J Epidemiol 120: 653-669.

Standiford TJ, Kunkel SL, Phan SH, Rollins BJ, Strieter RM 1991. Alveolar macrophage-derived cytokines induce monocyte chemoattractant protein-1 expression from human pulmonary type II-like epithelial cells. J Biol Chem 266: 9912-9918.

Wagner AD, Goronzy JJ, Matteson EL, Weyand CM 1995. Systemic monocyte and T-cell activation in a patient with human parvovirus B19 infection. Mayo Clin Proc 70: 261-265.

Watanabe M, Shimamoto Y, Yamaguchi M, Inada S, Miyazaki S, Sato H 1994. Viral-associated haemophagocytosis and elevated serum TNF-alpha with parvovirus-B19-related pancytopenia in patients with hereditary spherocytosis. Clin Lab Haematol 16: 179-182.

Webster DP, Farrar J, Rowland-Jones S 2009. Progress towards a dengue vaccine. Lancet Infect Dis 9: 678-687.

Yaegashi N, Niinuma T, Chisaka H, Watanabe T, Uehara S, Okamura K, Moffatt S, Sugamura K, Yajima A 1998. The incidence of, and factors leading to, parvovirus B19-related hydrops fetalis following maternal infection; report of 10 cases and meta-analysis. J Infect 37: 28-35.

Yoshimura T, Yuhki N, Moore SK, Appella E, Lerman MI, Leonard EJ 1989. Human monocyte chemoattractant protein-1 (MCP-1). Full-length cDNA cloning, expression in mitogen-stimulated blood mononuclear leukocytes and sequence similarity to mouse competence gene JE. FEBS Lett 244: 487-493.

Young NS, Brown KE 2004. Parvovirus B19. N Engl J Med 350: 586-597. 